\title{
Correction to: First detection of two potyviruses, uraria mosaic virus and passiflora foetida virus $Y$, from passionfruit in Japan
}

\author{
Kota Nakasato ${ }^{1,3} \cdot$ Sayaka Fujioka ${ }^{1} \cdot$ Yuuji Sugawara $^{2} \cdot$ Tsuyoshi Ono $^{2} \cdot$ Takeshi Nishio $^{1} \cdot$ Shinya Tsuda $^{1}$ (I)
}

Published online: 5 July 2021

(c) The Phytopathological Society of Japan and Springer Japan KK, part of Springer Nature 2021

\section{Correction to: \\ Journal of General Plant Pathology (2020) 86:401-404 \\ https://doi.org/10.1007/s10327-020-00932-4}

In the original publication of the article, the article title should be changed from "First detection of two potyviruses, uraria mosaic virus and passiflora mosaic virus Y, from passionfruit in Japan" to "First detection of two potyviruses, uraria mosaic virus and passiflora foetida virus Y, from passionfruit in Japan".

Publisher's Note Springer Nature remains neutral with regard to jurisdictional claims in published maps and institutional affiliations.

The original article can be found online at https://doi.org/10.1007/ s10327-020-00932-4.

Shinya Tsuda

stsuda@hosei.ac.jp

1 Department of Clinical Plant Science, Faculty of Bioscience, Hosei University, Koganei, Tokyo 184-8584, Japan

2 Ogasawara Subtropical Branch of Tokyo Metropolitan Agriculture and Forestry Research Center, Komagari, Chichijima, Ogasawara, Tokyo 100-2101, Japan

3 Present Address: Department of Plant Biology, Michigan State University, East Lansing, MI 48824, USA 